\title{
Effects of hemicastration at various ages and of oestradiol-17 $\beta$ on plasma concentrations of gonadotrophins and androgens, testicular growth and interstitial cell responses in prepubertal lambs
}

\author{
N. Jenkins and G. M. H. Waites \\ Department of Physiology \& Biochemistry, University of Reading, Whiteknights, Reading RG6 2AJ, \\ U.K.
}

\begin{abstract}
Summary. The effect of the removal of one testis from cross-bred lambs at 1, 4, 8 or 12 weeks of age on plasma FSH, LH and testosterone was studied until 16 weeks of age. Hemicastration at all ages elicited a significant increase in plasma FSH compared to controls without a corresponding change in plasma LH or testosterone. The raised FSH after hemicastration at 1 or 4 weeks of age was suppressed to control levels between weeks 7 and 8 ; such a suppression was not observed in the 4 weeks following hemicastration at 8 or 12 weeks of age. The weight of the remaining testis had increased compared with the control by 12 weeks of age after hemicastration at 1 week $(+69 \%), 4$ weeks $(+13 \%)$ and 8 weeks $(+40 \%)$; hemicastration at 12 weeks of age also resulted in growth of the remaining testis at 16 weeks $(+82 \%)$. The total androgen production of interstitial cells in response to ovine $\mathrm{LH}$ stimulation in vitro did not differ significantly between lambs of 1 and 12 weeks of age, or in animals of 4,8 and 12 weeks of age after hemicastration at 1 week of age.

Subdermal implantation of oestradiol-17 $\beta$ into 1 -week hemicastrated lambs at the time of operation or at 6 weeks of age increased plasma oestradiol concentrations by approximately 2 -4-fold, prevented the $\mathrm{FSH}$ and testicular growth responses to hemicastration and suppressed plasma LH and testosterone to levels lower than those in control lambs. The total androgen response of interstitial cells from the remaining testis of oestradiol-implanted lambs at 12 weeks of age was significantly reduced.

We suggest that the pituitary-testis axis varies in sensitivity during the prepubertal period although the interstitial cellular response of the testis to $\mathrm{LH}$ stimulation remains constant.
\end{abstract}

\section{Introduction}

It has been known for some time and for a wide range of mammalian species that the removal of one testis may cause compensatory hypertrophy of the remaining testis, particularly if the operation is done early in life (see Waites, Wenstrom, Crabo \& Hamilton, 1983, for references). This surgical manoeuvre has been used to perturb the pituitary-testis axis in lambs in order to reveal some of the endocrine mechanisms associated with the hypertrophy (Walton, Evins \& Waites, 1978; Walton, Evins, Hillard \& Waites, 1980), but the observations have been conflicting in some respects. For example, neonatal hemicastration yielded an augmented secretion of FSH lasting for several weeks (Walton et al., 1978, 1980) without any evidence of other anterior pituitary hormones being 
involved (Waites et al., 1983) whereas Hochereau-de-Reviers et al. (1980) reported that hemicastration of lambs at 6 weeks of age elicited an increase of plasma LH concentrations without a significant elevation of FSH. This could reflect differences in the pituitary-gonadal axis due to age.

Walton et al. $(1978,1980)$ observed that the elevated plasma FSH concentration evoked by hemicastration at 1 week of age was sharply suppressed to values close to control levels in the period 8-10 weeks of age. This also occurred in lambs of a different breed in the U.S.A. (Waites et al., 1983) and the period of FSH suppression coincided with the maximum growth phase of several tissue elements in the remaining testis, particularly the Sertoli cells.

It was of interest, therefore, to establish whether hemicastration of prepubertal lambs at different ages elicited different endocrine responses and to attempt to identify the nature of the agent suppressing the secretion of FSH at about 8 weeks of age. Since exogenous oestradiol can alter plasma gonadotrophin concentrations in the adult ram (Schanbacher, 1979), we therefore investigated whether oestradiol in hemicastrated lambs would modify the gonadotrophin, testicular growth and interstitial cellular responses.

The plasma testosterone concentrations of neonatally hemicastrated lambs remained similar to those in control lambs (Walton et al., 1978, 1980; Waites et al., 1983). One mechanism whereby this could occur, despite the loss of half the interstitial tissue, would be if the remaining testis had an increased responsiveness to LH. Therefore, the in-vitro responsiveness to ovine $\mathrm{LH}$ of interstitial cells from lambs hemicastrated at 1 week of age was compared with that of cells from control lambs during the prepubertal period.

\section{Materials and Methods}

\section{Animals}

Cross-bred lambs ( $50 \%$ Suffolk : $25 \%$ Blue-faced Leicester : $25 \%$ Swaledale) which were born in March 1981 were reared in sheds under conditions of natural photoperiod (latitude $51 \cdot 5^{\circ} \mathrm{N}$ ) and temperature. The 26 lambs were separated from the ewes during the first week of life and fed on milk substitute (Lamlac, Volac, Royston, Herts, U.K.) until 5 weeks of age when they were weaned onto pelleted concentrates (Volac).

\section{Surgery}

Groups of 4 lambs were hemicastrated at 1, 4,8 or 12 weeks of age. At operation, the lamb was anaesthetized by an intravenous injection of ketamine chloride (Vetalar: Parke-Davis, Pontypool, U.K.) or of pentobarbitone sodium (Sagatal: May \& Baker Ltd, Dagenham, Essex, U.K.) followed by halothane (May \& Baker)-oxygen and one testis and its associated epididymis were removed. The operation lasted less than $20 \mathrm{~min}$. The second testis was removed at 12 or 16 weeks of age (Table 1).

Six additional lambs were hemicastrated at 1 week of age and capsules containing oestradiol-17ß (Compudose, Eli Lilly \& Sons, Basingstoke, Hants, U.K.), were implanted subdermally at the base of the ear, 4 on the same day as hemicastration (mean capsule weight $160 \mathrm{mg}$ ) and 2 at 6 weeks of age (mean capsule weight $420 \mathrm{mg}$ ). All capsules were removed and reweighed when the remaining testis was removed at 12 weeks of age.

Blood $(8-10 \mathrm{ml})$ was taken from the jugular vein between $10: 00$ and $11: 00 \mathrm{~h}$ at weekly intervals. More frequent samples (every $20 \mathrm{~min}$ for $5 \mathrm{~h}, 2 \mathrm{ml}$ ) were taken by means of a jugular vein catheter implanted $1 \mathrm{~h}$ before sampling at 6 weeks to measure luteinizing hormone (LH) concentrations. Each sample was transferred to an ice-cold tube containing heparin $(50 \mathrm{i} . \mathrm{u} . / \mathrm{ml})$, centrifuged at $800 \mathrm{~g}$ for $10 \mathrm{~min}$, and the plasma was separated and stored at $-20^{\circ} \mathrm{C}$ until assayed. 


\section{Radioimmunoassays}

Plasma concentrations of FSH and LH were determined using a micromodification (Follett, Farner \& Mattocks, 1975) of the radioimmunoassays described for LH (Walton, McNeilly, McNeilly \& Cunningham, 1977) and FSH (McNeilly, McNeilly, Walton \& Cunningham, 1976). The coefficients of variation ranged from 8 to $11 \%$ within assays, and from 11.5 to $14 \%$ between assays, and the limits of assay sensitivity were $0.1 \mathrm{ng} / \mathrm{ml}$ for NIH-LH-S16 and $18 \mathrm{ng} / \mathrm{ml}$ for NIH. FSH-S8. Steroid concentrations were determined in pooled plasma samples $(2 \mathrm{ml})$ from the 4 animals in each group after extraction with diethyl ether $(2 \times 10 \mathrm{ml})$ and chromatographed on Celite columns, as described by Hodges, Eastman \& Jenkins (1983). Mean \pm s.e.m. recovery values, as determined from individual radiotracer losses through extraction and chromatography were as follows: testosterone, $72 \pm 1.8 \%(n=12), 5 \alpha$-dihydrotestosterone, $54 \pm 6.5 \%(n=12)$, oestradiol-17 $\beta, 69 \pm 2 \cdot 0 \%(n=18)$. Specific antisera were used to radioimmunoassay the resultant fractions (Hodges et al., 1983) and the limits of assay sensitivity were $30 \mathrm{pg}$ testosterone $/ \mathrm{ml}, 20 \mathrm{pg}$ $5 \alpha$-dihydrotestosterone $/ \mathrm{ml}$ and $8 \mathrm{pg}$ oestradiol- $17 \beta / \mathrm{ml}$ respectively. To eliminate errors due to interassay variation, all samples were assayed in triplicate in a single assay for each steroid. The intraassay coefficients of variation in control plasma pools of ram plasma were $7 \cdot 8 \pm 0.9 \%(n=6)$ for testosterone, $10.0 \pm 1.2 \%(n=6)$ for $5 \alpha$-dihydrotestosterone, and $11.0 \pm 1.0 \%(n=6)$ for oestradiol-17 $\beta$.

\section{Interstitial cell assays}

Testes were decapsulated, minced and dispersed in collagenase (Sigma Type III, 70 units/ml) using methods described previously (Jenkins, Sumpter \& Follett, 1978). The resultant interstitial cell suspension was incubated for $3 \mathrm{~h}$ at $37^{\circ} \mathrm{C}$ with various doses of ovine LH (NIH-LH-S16). The incubation was terminated by centrifugation $(180 \mathrm{~g}, 5 \mathrm{~min})$ and the supernatant was assayed for androgens using an antiserum raised in rabbits against testosterone-3-carboxymethyloxime-BSA conjugate, which has a $66 \%$ cross-reaction to $5 \alpha$-dihydrotestosterone (DHT) and $5 \%$ to $5 \alpha$ -

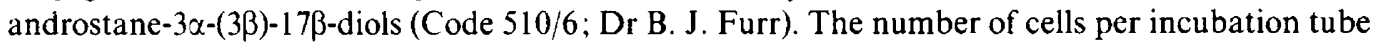
was calculated using a 'Coulter Counter' (Coulter Electronics Co.) and the androgen concentration was expressed as a function of the cell number in each tube. The androgen production from interstitial cells isolated from control 12-week-old testes, stimulated by the same doses of $\mathrm{LH}$ and in the presence of $300 \mathrm{nM}$-oestradiol-17 7 (Sigma Chemicals), was also determined.

\section{Statistical analyses}

Mean concentrations of plasma hormones, and areas under the curves of hormone concentration against time were compared using Student's independent $t$ test. Student's correlated $t$ test was used for comparing hormone levels in plasma over consecutive weeks. Regression analysis was performed on the dose-response curves obtained by stimulating interstitial cells with 25-400 $\mathrm{ng} \mathrm{LH} / \mathrm{ml}$, and compared between groups using Student's independent $t$ test.

\section{Results}

Body weight increased from $4.4 \pm 0.18 \mathrm{~kg}$ at birth to $27.5 \pm 0.91 \mathrm{~kg}$ at 12 weeks, with no significant differences between the groups.

\section{Testicular hypertrophy}

The weight of the remaining testis after hemicastration at 1 week of age progressively increased with age and became significantly different from control testes by 8 weeks (Table 1). This hypertrophy was also apparent in lambs hemicastrated at 4, 8 or 12 weeks of age (Table 1). 
Table 1. The weights of single testes from control lambs and lambs hemicastrated at $1,4,8$ or 12 weeks of age and of 1 -week hemicastrated lambs implanted with oestradiol

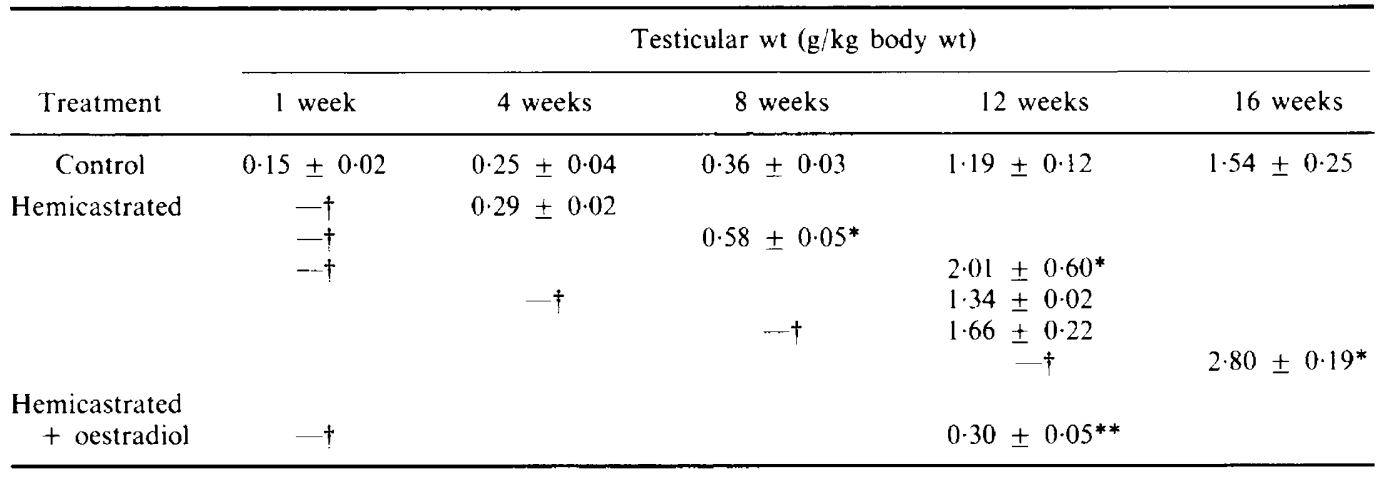

Values are mean \pm s.e.m. for 12 control lambs at 1 week and 4 control lambs at 4-16 weeks: for 4 hemicastrated lambs; and for 6 hemicastrated + oestradiol-treated lambs.

$\uparrow$ Removal of first testis.

* Significantly different from control value, $P<0.05$.

** Significantly different from equivalent value for hemicastrated lambs, $P<0.001$.

Oestradiol implantation arrested testicular growth at the size equivalent to that seen when the capsule was implanted (Table 1). The mean concentration of oestradiol in pooled plasma samples was $30 \pm 10 \mathrm{pg} / \mathrm{ml}$ in lambs given implants at 1 week of age and $60 \mathrm{pg} / \mathrm{ml}$ in lambs with implants at 6 weeks of age; values in control and untreated hemicastrated lambs were below the limits of sensitivity of the assay.

\section{Hormones}

FSH. Hemicastration at all ages resulted in elevations in circulating concentrations of FSH compared to controls (Text-fig. 1). In lambs hemicastrated at 1 or 4 weeks of age the raised FSH concentrations were sharply suppressed toward control values $(55 \pm 10 \mathrm{ng} / \mathrm{ml})$ between 7 and 8 weeks of age; such a suppression was not observed in the 4 weeks following removal of one testis at 8 or 12 weeks of age. The mean area under the curve ( $\mathrm{ng} / \mathrm{ml} /$ week) for FSH in the 4 weeks after hemicastration was greater for lambs hemicastrated at 4 weeks $(635 \pm 138)$ or 8 weeks $(640 \pm 136)$ than for lambs operated on at 1 week $(477 \pm 46)$ or 12 weeks $(421 \pm 36)$. The differences were not statistically significant owing to the small number of animals in each group. Removal of the second testis resulted in extremely elevated concentrations of FSH which ranged from 550 to $800 \mathrm{ng} / \mathrm{ml}$ at 2 weeks after the operation and declined thereafter.

Treatment of hemicastrated lambs with oestradiol at 1 week or 6 weeks of age prevented the FSH response in lambs given implants at 1 week of age, and suppressed the elevated FSH when implants were given at 6 weeks to levels lower than those in unoperated controls (Text-fig. 2).

$L H$. The area under the plasma $\mathrm{LH}$ concentration against time curve was similar in lambs hemicastrated at 1 week $(3.49 \pm 0.76 \mathrm{ng} / \mathrm{ml} / \mathrm{h})$ and in intact lambs $(3.57 \pm 0.86 \mathrm{ng} / \mathrm{ml} / \mathrm{h})$ when sampled over a 5 -h period at 6 weeks of age. Oestradiol implantation resulted in significantly lower levels of LH than in control lambs of the same age $(1.74 \pm 0.07 \mathrm{ng} / \mathrm{ml} / \mathrm{h})$. The mean number of $\mathrm{LH}$ pulses in the $5 \mathrm{~h}$ sample period was similar in control (1.75) and in hemicastrated (1.50) lambs but only a single pulse was observed in one of the lambs treated with oestradiol.

Androgens. The circulating concentrations of testosterone remained low in lambs hemicastrated at 1 week of age and in intact controls until 6 weeks of age $(60-230 \mathrm{pg} / \mathrm{ml})$ and thereafter slowly increased in both groups until 12 weeks $(580-620 \mathrm{pg} / \mathrm{ml}$, Text-fig. 3). Following oestradiol implantation, the plasma testosterone concentrations remained low $(<100 \mathrm{pg} / \mathrm{ml})$ throughout the 


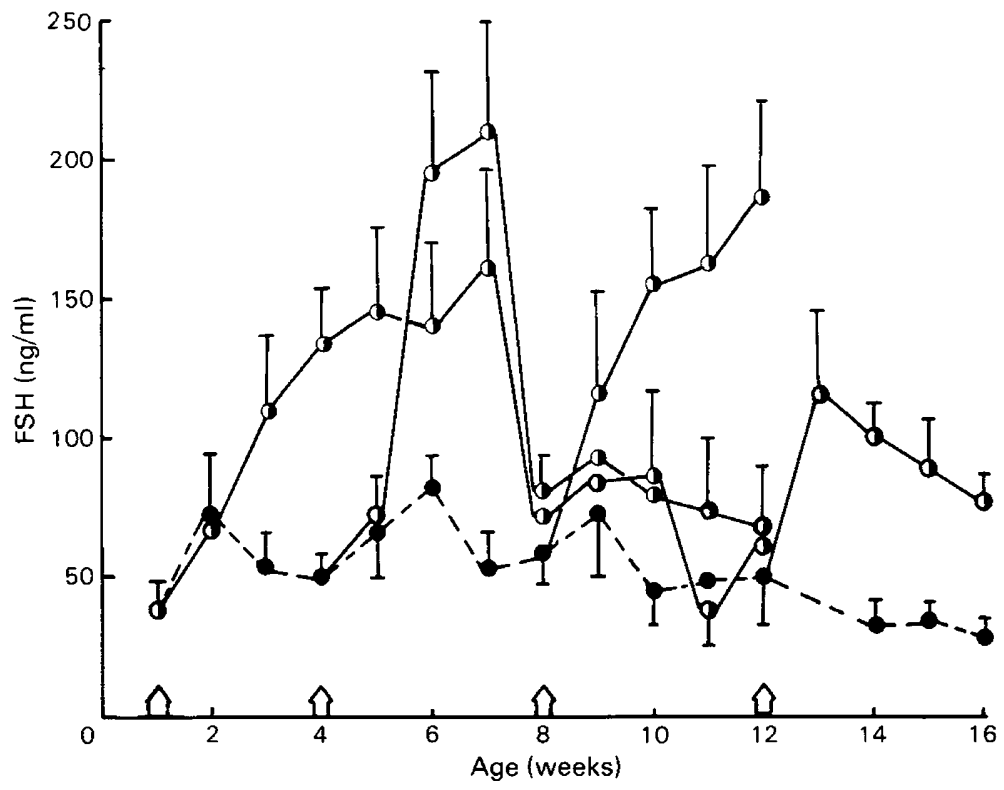

Text-fig. 1. Plasma concentrations of FSH in control lambs (O) and in lambs hemicastrated (C) at $1,4,8$ or 12 weeks of age (arrows). Values are mean \pm s.e.m.; for controls and lambs hemicastrated at 1 week: $N=12$ for Weeks $1-4 ; 8$ for Weeks $5-8$; and 4 for Weeks $9-12$. For all other groups, $\mathrm{N}=4$.

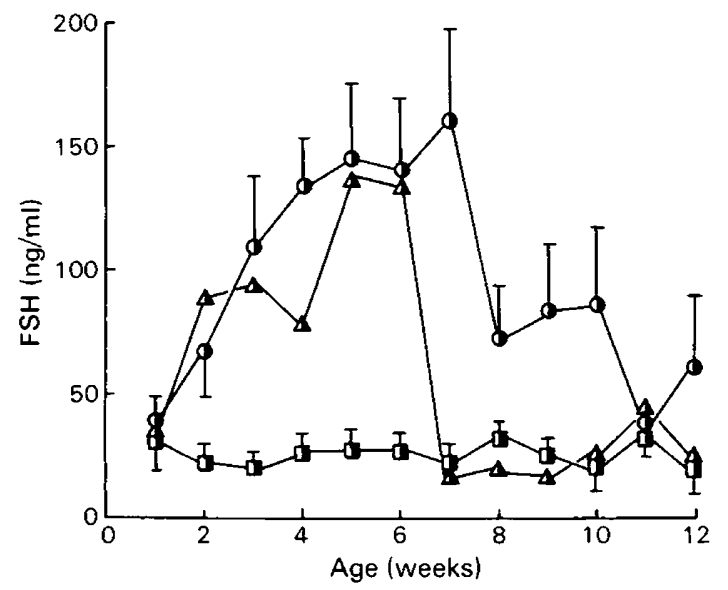

Text-fig. 2. Plasma concentrations of FSH in lambs hemicastrated at 1 week of age (O) or hemicastrated at 1 week plus oestradiol implants at 1 week $(\square)$ or at 6 weeks $(\boldsymbol{\Delta})$. Values are means \pm s.e.m. for $\boldsymbol{O}, \mathrm{N}=12$, Weeks $1-4 ; \mathrm{N}=8$, Weeks $5-8$; and $\mathrm{N}=4$, Weeks 9-12; for $\square, \mathbf{N}=4 ;$ for $\Lambda, N=2$.

12-week period. Plasma concentrations of $5 \alpha$-dihydrotestosterone were below the limits of sensitivity of the assay in all samples.

\section{Interstitial cell assays}

The average number of cells incubated in each tube ranged from 1.20 to $2.48 \times 10^{6}$. Basal androgen production in the absence of LH was uniformly low $\left(0 \cdot 33-0.61 \mathrm{ng} / 10^{6}\right.$ cells $)$ and did not 


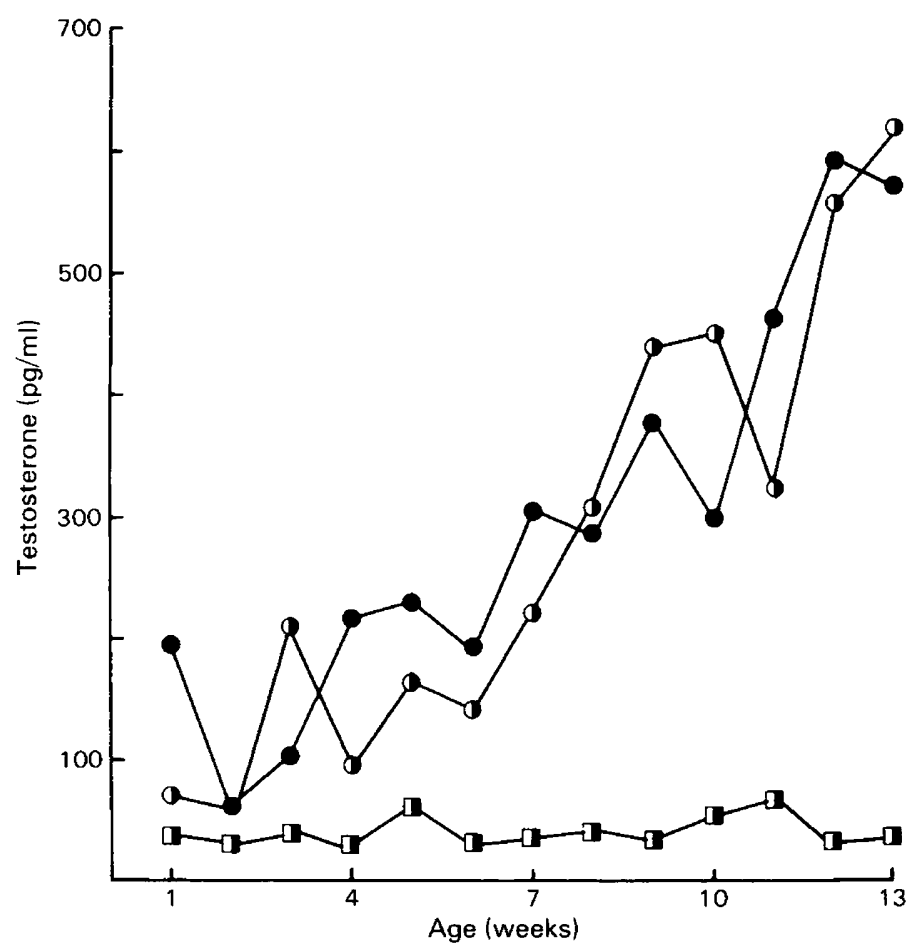

Text-fig. 3. Plasma concentrations of testosterone (pooled samples) in control lambs (O), lambs hemicastrated at 1 week of age (O), and lambs hemicastrated and implanted with oestradiol at 1 week of age (ㅁ).

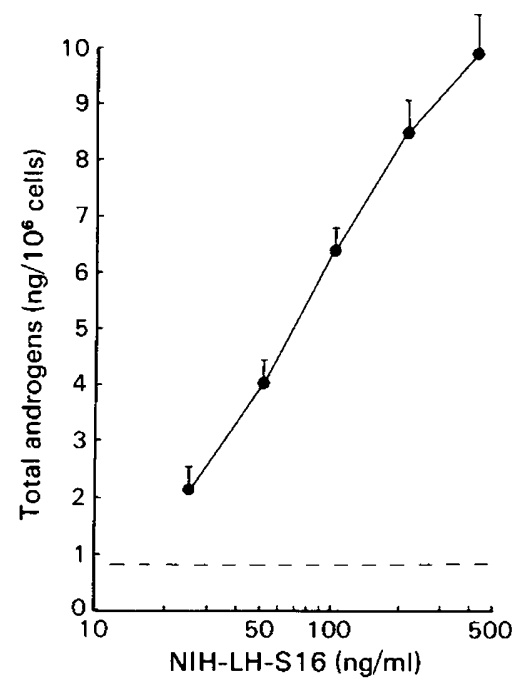

Text-fig. 4. The effect of various doses of ovine LH (note logarithmic scale) on the release of androgens from interstitial cells isolated from testes of l-week-old lambs. Values are mean \pm s.e.m. for 6 replicates. The broken line represents the limit of sensitivity of the assay. 
differ significantly in the cells of different groups. The androgen response in all groups was highly correlated with the dose of LH ( $r=0.97-0.99$; Text-fig. 4) and the slope of the dose-response curve ranged from 0.012 to 0.017 in hemicastrated and control groups, and from 0.005 to 0.007 in all cell suspensions from lambs implanted with oestradiol.

No significant differences were detected in the total androgen response to LH in Leydig cells from hemicastrated and control lambs of different ages (Text-fig. 5) or between hemicastrated lambs and controls at 12 weeks of age. The androgen response to $\mathrm{LH}$ of cells from the remaining testis of lambs which had received oestradiol implants was reduced compared to that of hemicastrated or control lambs at 12 weeks of age (Text-fig. $5, P<0.05$ ), and the effect was similar regardless of the age of the lamb at oestradiol implantation. However, the androgen response of interstitial cells from control lambs at 12 weeks of age was not altered by the addition of $300 \mathrm{nM}$ oestradiol-17 $\beta$ to the incubation medium.

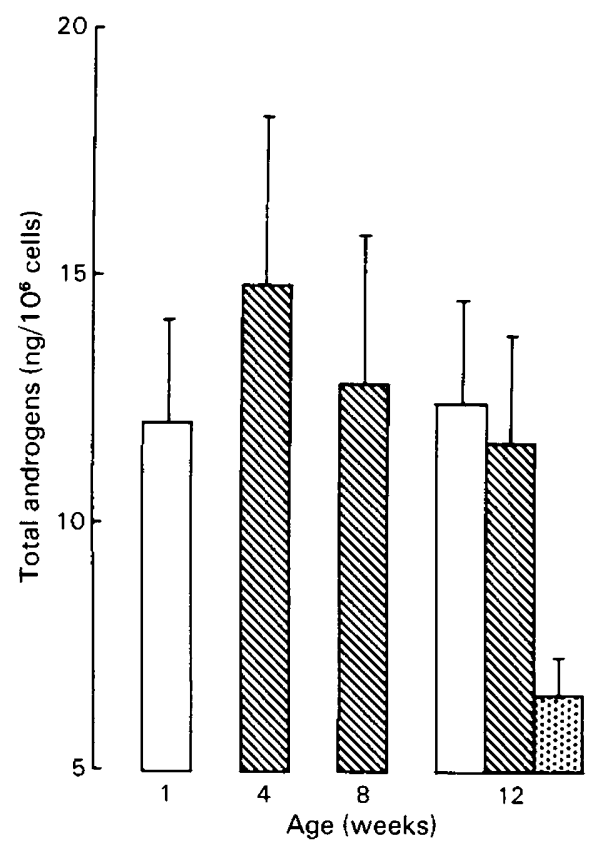

Text-fig. 5. Total androgen production by interstitial cells after stimulation with ovine $\mathrm{LH}$ at the doses shown in Text-fig. 4. Values are mean \pm s.e.m.; $\square$, control lambs at 1 and 12 weeks of age $(N=4) ; \mathbb{N}, 4-, 8-$, or 12 -week-old lambs, hemicastrated at 1 week of age $(N=4)$; 臤, hemicastrated at 1 week and implanted with oestradiol at 1 week or 6 weeks $(N=6)$.

\section{Discussion}

Hemicastration of lambs at all ages during the prepubertal period resulted in a rapid elevation of circulating concentrations of FSH. The 4 week post-operative response was greater in lambs of 4 or 8 weeks of age than in lambs at 1 or 12 weeks. However, the FSH response to hemicastration at 1 week was maintained throughout the early prepubertal period and was suppressed to control values by 8 weeks, as shown in previous studies (Walton et al., 1978, 1980; Waites et al., 1983); this suppression was also observed when hemicastration was delayed until 4 weeks of age. The FSH elevation after the removal of one testis at 8 weeks was still rising 4 weeks later in contrast to the smaller response observed after hemicastration at 12 weeks which slowly declined (Text-fig. 1). 
Although daylength and season of birth can modify testicular development in the lamb (de Reviers et al., 1980), the lengthening photoperiod is unlikely to account for the changes in FSH responses to hemicastration because their magnitude is not directly correlated with daylength. However, differing FSH responses could be due to changes in the production of testicular feedback agents or to alterations in the sensitivity of the hypothalamo-hypophysial complex (Foster, Cruz, Jackson, Cook \& Nalbandov, 1972; Lee et al., 1976; Savoie et al., 1979).

Our results indicate that the control of FSH secretion is critical to the maturation of the pituitary-testis axis in lambs since neonatal hemicastration did not significantly alter the character or pattern of LH secretion in the early prepubertal period, as previously shown (Walton et al., 1978, 1980; Waites et al., 1983). Moreover the dramatic suppression at 7-8 weeks of the elevated FSH levels in hemicastrated lambs suggests that a testicular feedback agent capable of modulating FSH has appeared by this age. We do not believe that this agent is testosterone because the magnitude of the FSH responses to hemicastration at 4 and 8 weeks are similar despite the two-fold difference in preoperative testosterone levels at these ages (Text-fig. 3). Furthermore, $5 \alpha$-dihydrotestosterone levels remain undetectable after hemicastration and so this metabolite is unlikely to have a physiological effect in the control of gonadotrophin secretion. On the other hand, as previously reported (Walton et al., 1980), 'inhibin' of testicular origin is a putative modulator of FSH secretion (Franchimont et al., 1978; Cahoreau, Blanc, Dacheux, Pisselet \& Courot, 1979). A possible agent acting to suppress FSH secretion in lambs at 8 weeks of age could be an 'inhibin' produced by hypertrophied Sertoli cells. The FSH response to removal of a testis from control lambs at 8 weeks of age implies that the production of 'inhibin' in the remaining testis is insufficient to modulate pituitary secretion of FSH. The reduced and unsustained FSH response to hemicastration at 12 weeks of age perhaps reflects the impact of the onset of spermatogenesis on the hypothalamohypophysial complex.

The enhanced growth response of the remaining testis after hemicastration at 1 week of age progressively increased with age (Table 1), as seen previously (Waites et al., 1983). This hypertrophy was less when hemicastration was delayed until 4 or 8 weeks of age although a significant growth response to hemicastration was still apparent between 12 and 16 weeks of age. Although the immediate FSH responses to removing one testis at 4 or 8 weeks were greater than at 1 week, the total FSH response after neonatal hemicastration was maintained throughout the early postnatal period (Text-fig. 1) when Sertoli cells are capable of their optimal growth response (Ortavant, Courot \& Hochereau-de-Reviers, 1977; Waites et al., 1983). The testicular response to hemicastration at 12 weeks may depend upon other factors, for example, a stimulatory action of FSH on fluid secretion by mature Sertoli cells (see Waites \& Gladwell, 1982, for review) and, indirectly, on the development of spermatogenesis which is being initiated at this time (Waites et al., 1983).

The steroidogenic response to ovine LH of enzyme-dispersed interstitial cells from 1- and 12week-old lambs did not differ and was unaffected by neonatal hemicastration (Text-fig. 5). These results are supported by the observation that the androgen responses in vivo to hCG injections into lambs at 1, 4 or 8 weeks of age were similar (Garnier \& Saez, 1980), although the testosterone production in vitro following hCG administration in vivo was greatest at 1 week of age (Savoie et al., 1980). Hamel et al. (1981) concluded from in-vitro stimulation with hCG that the steroidogenic capacity of the lamb testis attained a plateau at 2-4 weeks of age. Despite our reservations concerning data obtained using heterologous gonadotrophic stimulation, these observations, together with ours, suggest that the low levels of plasma testosterone in neonatal lambs (Text-fig. 3; Foster et al., 1978) are probably due to low levels of pulsatile LH secretion or to limited numbers of functionally active Leydig cells rather than to insensitivity of individual cells. Similarly, the maintenance of normal circulating concentrations of testosterone after the removal of one testis at 1 week of age (Text-fig. 3) is probably not due to an increased responsiveness to LH. A more likely explanation is an immediate recruitment of functionally active Leydig cells, and the hypertrophy of the interstitium of the remaining testis that has been shown by morphometric analysis to occur after 
neonatal hemicastration (Waites et al., 1983). Hypertrophy and increased secretion of testosterone by the testis has been reported in 14-month-old sheep hemicastrated at 5-6 months of age (Lindner, 1969).

Raising the circulating levels of oestradiol at 1 week of age prevented the FSH and testicular growth responses normally displayed after hemicastration, and oestradiol implantation at 6 weeks of age reduced $\mathrm{LH}$ and $\mathrm{FSH}$ levels in hemicastrated lambs and arrested the growth of the remaining testis. In adult wethers a similar reduction in gonadotrophin levels was provoked by the subcutaneous injection of oestradiol dipropionate $(2 \mathrm{mg} /$ day), dihydrotestosterone propionate ( $20 \mathrm{mg} / \mathrm{day})$ but not by testosterone propionate $(20 \mathrm{mg} /$ day; Parrott \& Davies, 1979). Schanbacher (1979) reported a dose-related reduction in plasma concentrations of LH and FSH in castrated and cryptorchid rams after oestradiol implantation, and active immunization of intact rams against oestradiol or testosterone resulted in an elevation of gonadotrophin levels. Although the plasma levels of oestrogen induced in these studies are likely to be supra-physiological, these data illustrate the inhibitory effects of oestradiol in male sheep. Furthermore, passive immunization against oestrone and oestradiol between 14 and 26 weeks of age slightly increased the rate of testicular growth in Merino rams without significantly altering the circulating levels of LH and FSH at 18 weeks (Land, Baird \& Carr, 1981). However, the production of oestradiol in adult rams is low and does not vary with season (Schanbacher \& Ford, 1976). Thus the evidence remains inconclusive that oestradiol could mediate the changes in FSH levels and testicular growth after hemicastration, and lambs passively immunized against oestradiol are now being studied.

Oestradiol concentrations of less than $300 \mathrm{nM}$ did not alter the androgen response of interstitial cells to ovine LH (Text-fig. 5) as was found in rats (Grotjan, Rodriguez-Rigau \& Steinberger, 1980). Therefore, the reduced steroidogenic response of interstitial cells from oestradiol-implanted lambs (Text-fig. 5) is likely to be due to reduced stimulation of Leydig cells by LH in vivo. Leydig cell responsiveness to exogenous gonadotrophins in the sheep was increased by previous exposure to hCG (Garnier \& Saez, 1980), which supports this suggestion.

In conclusion, our results support the view that FSH is the principal prepubertal influence on testicular development and growth in the lamb.

We thank Ms E. Henley, B.Sc. and Jo Hostford for their devoted care of the lambs and assistance with the radioimmunoassays; Dr J. I. Wilkinson (Eli Lilly \& Sons) for 'Compudose', and Dr B. Morris (University of Surrey) and Dr B. J. Furr (I.C.I. Pharmaceuticals) for steroid antisera. The work was supported by Grant AG45/192 from the Agricultural Research Council.

\section{References}

Cahoreau, C., Blanc, M.R., Dacheux, J.-L., Pisselet, C. \& Courot, M. (1979) Inhibin activity in ram rete testis fluid: depression of plasma FSH and LH in the castrated and cryptorchid ram. J. Reprod. Fert, Suppl. 26, 97-116.

de Reviers, M., Hochereau-de Reviers, M.-T., Blanc, M.R., Brillard, J.P., Courot, M. \& Pelletier, J. (1980) Control of Sertoli and germ cell populations in the cock and sheep testis. Reprod. Nutr. Develop. 20, 241 . 249.

Follett, B.K., Farner, D.S. \& Mattocks, P.W. (1975) Luteinizing hormone in the plasma of white-crowned sparrows (Zonotrichia leucophrys gambelii) during artificial photostimulation. Gen. comp. Endocr. 26, 126-134.

Foster, D.L., Cruz, T.A.C., Jackson, G.L., Cook, B. \& Nalbandov, A.V. (1972) Regulation of luteinizing hormone in the fetal and neonatal lamb. III. Release of LH by the pituitary in rivo in response to crude ovine hypothalamic extract or porcine gonadotropin releasing factor. Endocrinology 90, 673-683.

Foster, D.L., Mickelson, I.H., Ryan, K.D., Coon, G.A., Drongowski, R.A. \& Holt, J.A. (1978) Ontogeny of pulsatile luteinizing hormone and testosterone secretion in male lambs. Endocrinology 102. 1137-1146.

Franchimont, P., Demoulin, A., Verstraelen-Proyard, J., Hazee-Hagelstein, M.T., Walton, J.S. \& Waites, G.M.H. (1978) Nature and mechanisms of action of inhibin: perspective in regulation of male fertility. Int. J. Androl., Suppl. 2, 69-80.

Garnier, F. \& Saez, J.M. (1980) Response of plasma testosterone to human chorionic gonadotropin stimulation in the ram. Biol. Reprod. 22, 832-836.

Grotjan, H.E., Rodriguez-Rigau, L.J. \& Steinberger, E. 
(1980) Estradiol-induced inhibition of testosterone production by testicular interstitial cells incubated in vitro. J. Androl. 1, 138-144.

Hamel, R., Forest, M.G., Haour, F., Polychronakos, C., Charpenet, G., Gibb, W., Collu, R. \& Ducharme, J.R. (1981) Perinatal activity of the hypothalamic-pituitary-gonadal axis in the lamb. IV. Testicular responsiveness to hCG from 1 to 28 days of life. Hormone Res. 15, 179-188.

Hochereau-de-Reviers, M.-T., Blanc, M.R., Courot, M., Garnier, D.H., Pelletier, J, \& Poirier, J.C. (1980) Hormonal profiles and testicular parameters in the lamb. In Testicular Development, Structure and Function, pp. 237-247. Eds A. Steinberger \& E. Steinberger. Raven Press, New York.

Hodges, J.K., Eastman, S. \& Jenkins, N. (1983) Sex steroids and their relationship to binding proteins in the serum of the marmoset monkey Callithrix jacchnus. J. Endocr. 96, 443-450.

Jenkins, N., Sumpter, J.P. Follett, B.K. (1978) The effects of vertebrate gonadotrophins on androgen release in vitro from testicular cells of the Japanese quail and a comparison with their radioimmunoassay activities. Gen. comp. Endocr. 35, 309-321.

Land, R.B., Baird, D.T. \& Carr, W.R. (1981) Increased testicular growth of Tasmanian Merino ram lambs treated with antisera to oestrogens. J. Reprod. Fert. 62, 151-158.

Lee, V.W.K., Cumming, I.A., de Kretser, D.M., Findlay, J.K., Hudson, B. \& Keogh, E.J. (1976) Regulation of gonadotrophin secretion in rams from birth to sexual maturity. I. Plasma LH, FSH and testosterone levels. J. Reprod. Fert. 46, 1-6.

Lindner, H.R. (1969) The androgenic secretion of the testis in domestic ungulates. In The Gonads, pp. 615648. Ed. K. W. McKerns. Appleton-Century-Crofts, New York.

McNeilly, J.R., McNeilly, A.S., Walton, J.S. \& Cunningham, F.J. (1976) Development and application of a heterologous assay for ovine follicle-stimulating hormone. J. Endocr. 70, 69-79.

Ortavant, R., Courot, M. \& Hochereau-de Reviers, M.-T. (1977) Spermatogenesis in domestic animals. In Reproduction in Domestic Animals, pp. 203-227. Eds H. H. Cole \& P. T. Cupps. Academic Press, New York.

Parrott, R.F. \& Davies, R.V. (1979) Serum gonado- trophin levels in prepubertally castrated male sheep treated for long periods with propionated testosterone, dihydrotestosterone, 19-hydroxytestosterone or oestradiol. J. Reprod. Fert. 56, 543-548.

Savoie, S., Forest, M.G., Bourel, B., Saez, J.M., Collu, R., Bertrand, J. \& Ducharme, J.R. (1979) Perinatal activity of the hypothalamic-pituitary-gonadal axis in the lamb. I. Circulating levels of LH, FSH, prolactin and testosterone and the in vivo response to hCG in the first two months of life. Biol. Reprod. 21, 1051-1056.

Savoie, S., Forest, M.G., Bourel, B., Haour, F., Saez, J.M., Collu, R., Bertrand, J. \& Ducharme, J.R. (1980) Perinatal activity of the hypothalamic-pituitarygonadal axis in the lamb. II. In-vitro testicular response to human chorionic gonadotrophin and choleratoxin in the first 2 months of life. Hormone Res. 13, 186-195.

Schanbacher, B.D. (1979) The regulation of FSH secretion in rams. J. Reprod. Fert., Suppl. 26, 15-16.

Schanbacher, B.D. \& Ford, J.J. (1976) Seasonal profiles of plasma luteinizing hormone, testosterone and estradiol in the ram. Endocrinology 99, 752-757.

Waites, G.M.H. \& Gladwell, R.T. (1982) The physiological significance of fluid secretion in the testis and the blood-testis barrier. Physiol. Rev. 62, 624-672.

Waites, G.M.H., Wenstrom, J.C., Crabo, B.G. \& Hamilton, D.W. (1983) Rapid compensatory hypertrophy of the lamb testis following neonatal hemiorchidectomy: endocrine and light microscopical morphometric analyses. Endocrinology (in press).

Walton, J.S., McNeilly, J.R., McNeilly, A.S. \& Cunningham, F.J. (1977) Changes in the concentrations of follicle-stimulating hormone, luteinizing hormone, prolactin and progesterone in the plasma of ewes during the transition from anoestrus to breeding activity. $J$. Endocr. 75, 127-136.

Walton, J.S., Evins, J.D. \& Waites, G.M.H. (1978) Feedback control of follicle-stimulating hormone in pre- and postpubertal rams as revealed by hemicastration. J. Endocr. 77, 75-84.

Walton, J.S., Evins, J.D., Hillard, M.A. \& Waites, G.M.H. (1980) Follicle-stimulating hormone release in hemicastrated prepubertal rams and its relationship to testicular development. J. Endocr. 84, 141152.

Received 13 October 1982 